\title{
Effect of soluble factors derived from oral cancer cells on the production of interferon- $\gamma$ from peripheral blood mononuclear cells following stimulation with OK-432
}

\author{
GO OHE, AKIKO SASAI, DAISUKE UCHIDA, TETSUYA TAMATANI, HIROKAZU NAGAI and YOUJI MIYAMOTO
}

Department of Oral Surgery, Subdivision of Molecular Oral Medicine, Division of Integrated Sciences of Translational Research, Institute of Health Biosciences, The University of Tokushima Graduate School, Tokushima 770-8504, Japan

Received December 28, 2012; Accepted March 14, 2013

DOI: $10.3892 / o r .2013 .2480$

\begin{abstract}
The streptococcal antitumor agent OK-432 is commonly used as an immunopotentiator for immunotherapy in various types of malignant tumors including oral cancer. It has been demonstrated that OK-432 elicits an antitumor effect by stimulating immunocompetent cells, thereby inducing multiple cytokines including interferon (IFN) $-\gamma$, interleukin (IL)-2 and IL-12. Serum concentrations of IFN- $\gamma$ in patients with oral cancer were examined $24 \mathrm{~h}$ after administration of OK-432. Serum concentrations of IFN- $\gamma$ in patients with advanced cancer were significantly lower than those in patients with early cancer. These results suggested that some soluble factors produced by cancer cells may inhibit IFN- $\gamma$ production with OK-432. Thus, in the present study, an in vitro simulation model was established for the immune status of patients with oral cancer by adding conditioned medium (CM) derived from oral cancer cell lines into a culture of peripheral blood mononuclear cells (PBMCs) derived from a healthy volunteer. We investigated whether soluble factors derived from oral cancer cells affected IFN- $\gamma$ production from PBMCs following stimulation with OK-432. PBMCs stimulated with OK-432 produced a large amount of IFN- $\gamma$; however, both IFN- $\gamma$ production and cytotoxic activity from PBMCs induced by OK-432 were inhibited by the addition of CM in a dose-dependent manner. In order to examine these inhibitory effects against IFN- $\gamma$ production, the contribution of inhibitory cytokines such as IL-4, IL-6, IL-10, transforming growth factor- $\beta$ and vascular endothelial growth factor was investigated. However, neutralization of these inhibitory cytokines did not recover IFN- $\gamma$ production inhibited by $\mathrm{CM}$. These results indicated
\end{abstract}

Correspondence to: Dr Go Ohe, Department of Oral Surgery, Subdivision of Molecular Oral Medicine, Division of Integrated Sciences of Translational Research, Institute of Health Biosciences, The University of Tokushima Graduate School, 3-18-15 Kuramoto-cho, Tokushima 770-8504, Japan

E-mail: go.ohe@tokushima-u.ac.jp

Key words: OK-432, conditioned medium, interferon- $\gamma$, oral cancer that unknown molecules may inhibit IFN- $\gamma$ production from PBMCs following stimulation with OK-432.

\section{Introduction}

OK-432 is a penicillin-killed and lyophilized preparation of a low-virulence strain (Su) of Streptococcus pyogenes (group A) that was developed by Okamoto et al (1). OK-432 is a major cancer immunotherapy agent and has been shown to be effective against several types of cancer (2-5). We have also reported that OK-432 shows a strong antitumor effect against oral cancer in combination with radiotherapy and UFT, an oral fluoropyrimidine formulation combining tegafur and uracil in a $1: 4$ ratio $(6,7)$.

The main action mechanism of OK-432 is the induction and activation of cytotoxic macrophages, cytotoxic T lymphocytes, and antitumor effector cells such as natural killer (NK) cells and lymphokine-activated killer (LAK) cells. OK-432 also reportedly increases antitumor effects by increasing production of antitumor cytokines such as interferon (IFN)- $\gamma$, interleukin (IL)-2, IL-12, and tumor necrosis factor (TNF)- $\alpha$ by Th1 cells, NK cells, and monocytes/macrophages (8-12), and displays antitumor effects by inducing cancer antigen-specific cytotoxic $\mathrm{T}$ lymphocytes via maturation of antigen-presenting dendritic cells (13).

We have successfully isolated a lipoteichoic acid-related molecule, OK-PSA, which is an active component of OK-432 $(14,15)$. We have also demonstrated that OK-PSA exhibits antitumor effects by the induction of antitumor cytokine-producing Th1 cells (16-20). Moreover, we have clarified that the receptors against OK-PSA are Toll-like receptor (TLR) 4/MD-2 complexes that are expressed on the surface of immunocompetent cells (21-24). In addition, when the expression of either TLR4 or MD-2 is lost in peripheral blood mononuclear cells (PBMCs) in patients with oral cancer, the sensitivity to OK-432 is decreased (25). However, after administration of OK-432 in patients with oral cancer expressing both TLR4 and MD-2, diverse serum concentrations of IFN- $\gamma$ were detected, at ranges of $50-433 \mathrm{pg} / \mathrm{ml}$ (Fig. 1). Moreover, serum concentrations of IFN- $\gamma$ in patients with advanced cancer were lower than those in patients with early cancer. These results suggest that the responsiveness of OK-432 against patients with oral 
cancer is dependent on cancer progression and growth. Thus, we hypothesized that some types of soluble factors secreted by cancer cells may decrease the production of IFN- $\gamma$ with the administration of OK-432.

In the present study, we established an in vitro simulation model for immune status in cancer-burden patients by the addition of conditioned medium (CM) derived from oral cancer cells to PBMCs derived from healthy volunteers. Whether or not soluble factors derived from oral cancer cells affected IFN- $\gamma$ production of PBMCs following stimulation with OK-432 was then investigated.

\section{Materials and methods}

Investigation of the association between stage of oral cancer and serum concentration following OK-432 administration. We re-analyzed the clinical data described by Okamoto et al (25) on the association between serum levels of IFN- $\gamma$ and expression of TLR4 and MD- 2 following administration of OK-432 in patients with oral cancer. According to the International Union against Cancer (UICC) criteria (26) for tumor-node-metastasis (TNM) classification and cancer stage, 4 patients were stage II, 7 were stage III, and 2 were stage IV. Patients with oral cancer expressing both TLR4 and MD-2 were divided into early cancer (stages I and II) and advanced cancer (stages III and IV), and serum levels of IFN- $\gamma$ $24 \mathrm{~h}$ after administration of OK-432 were compared.

Cells and cell culture. B88 (27) and HNt cells (28), established in our laboratory, were derived from patients with oral squamous cell carcinoma (SCC), and TYS cells (29) were a human oral adenoid squamous carcinoma cell line derived from a minor salivary gland in the oral mucosa. All cells were maintained in DMEM (Sigma-Aldrich, St. Louis, MO, USA) supplemented with $10 \%$ (V/V) FBS (Bio-Whittaker, Walkersville, MD, USA), $100 \mu \mathrm{g} / \mathrm{ml}$ streptomycin, and $100 \mathrm{U} / \mathrm{ml}$ penicillin (Invitrogen, Carlsbad, CA, USA) in a humidified atmosphere of $95 \%$ air and $5 \% \mathrm{CO}_{2}$ at $37^{\circ} \mathrm{C}$. K-562 cells (30), a human erythroblastic leukemic cell line, Daudi cells (31), a human Burkitt's lymphoma cell line, and PBMCs derived from a healthy volunteer were maintained in RPMI-1640 (Sigma-Aldrich) supplemented with 10\% FBS.

Preparation of PBMCs. PBMCs were isolated from heparinized venous blood derived from a healthy volunteer by Ficoll-Hypaque gradient density centrifugation according to Boyüm's standard procedures (32).

Preparation of $C M$. Oral cancer cells $\left(2.5 \times 10^{6}\right.$ cells $)$ were grown in 100-mm dishes (Falcon; Becton-Dickinson Labware, Lincoln Park, NJ, USA) in complete culture medium for $48 \mathrm{~h}$ up to attaching the dishes. Then, cells were washed 3 times using phosphate-buffered saline (-) and were cultured for an additional $72 \mathrm{~h}$ in $10 \mathrm{ml}$ of serum-free media. Media were collected and purified by passing through $0.2 \mu \mathrm{m}$ polyethersulfone membranes (Corning Costar, Rochester, NY, USA), followed by subjection to experiments as CM.

In vitro simulation model of patients with oral cancer. PBMCs $\left(1 \times 10^{6}\right.$ cells $\left./ \mathrm{ml}\right)$ were seeded in RPMI-1640 containing $10 \%$

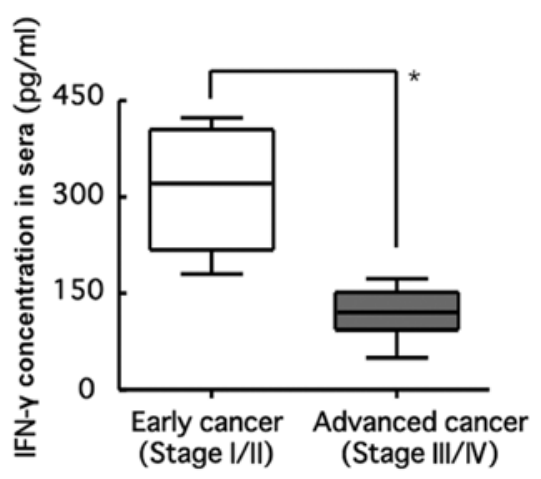

Figure 1. Association between cancer stage and serum concentration of IFN- $\gamma$ in patients with oral cancer following administration with OK-432. Serum concentrations of IFN- $\gamma$ were examined in patients with oral cancer expressing both TLR4 and MD-2, $24 \mathrm{~h}$ after $\mathrm{OK}-432$ administration. ${ }^{*} \mathrm{P}<0.05$.

FBS. Media were replaced with CM-containing media at a CM volume of $1 / 8,1 / 4$ or $1 / 2$. FBS and OK-432 (Chugai Pharmaceutical, Tokyo, Japan) were added to a final concentration of $10 \%$ and $1 \mu \mathrm{g} / \mathrm{ml}$, respectively.

Enzyme-linked immunosorbent assay (ELISA). Immunosuppressive cytokines [IFN- $\gamma$, IL-12, IL-4, IL-6, IL-10, transforming growth factor- $\beta$ (TGF- $\beta$ ) and vascular endothelial growth factor (VEGF)] in cell culture supernatant and CM were measured by an ELISA kit according to the manufacturer's instructions (BioSource International, Inc., Camarillo, CA, USA).

Measurement of cytotoxic activities. The cytotoxic activity of PBMCs was measured with a lactate dehydrogenase (LDH) release assay (33-35) using K-562 cells that exhibited sensitivity to human NK and Daudi cells without sensitivity to NK cells as target cells. Target cells were suspended in RPMI-1640 medium containing $1 \%$ FBS. After seeding in a proportion of $5 \times 10^{3}$ cells $/ 50 \mu 1$ per well in 96-well round-bottomed microplates (Corning Costar), $1 \times 10^{5}$ cells $/ \mu 1$ of PBMCs were added as effector cells. After $4 \mathrm{~h}$ of co-culture, the enzymatic activity of LDH released from the breakdown of target cells as a result of cytotoxic activity was measured using a Cytotoxicity Detection $\mathrm{Kit}^{\text {plus }}$ (Roche Diagnostics GmbH, Mannheim, Germany). Cytotoxic activity was calculated using the following formula: Cytotoxicity $(\%)=(\mathrm{A}-$ low control $) /($ high control - low control $)$ x 100; $\mathrm{A}=$ (effector-target cell mix - effector cell control).

High control indicates that cells showed absorbance in supernatant when Triton X-100 (Sigma-Aldrich) was dissolved in target cells. Low control cells showed absorbance in supernatant when only target cells were cultured. The effectortarget cell mix shows absorbance in supernatant from a mixed culture of effector cells and target cells, and effector cell control shows absorbance in supernatant when only effector cells were cultured.

Treatment of PBMCs with neutralizing antibodies (Abs). CM was treated for $2 \mathrm{~h}$ at $37^{\circ} \mathrm{C}$ with the following neutralizing Abs; anti-IL-4 Ab (clone 3007; $750 \mathrm{ng} / \mathrm{ml}$ ), anti-IL-6 Ab (clone 6708; $75 \mathrm{ng} / \mathrm{ml}$ ), anti-IL-10 Ab (clone 25209; $250 \mathrm{ng} / \mathrm{ml}$ ), anti-TGF- $\beta$ $\mathrm{Ab}$ (clone 27235; $500 \mathrm{ng} / \mathrm{ml}$ ), or anti-VEGF Ab (clone 26503; 


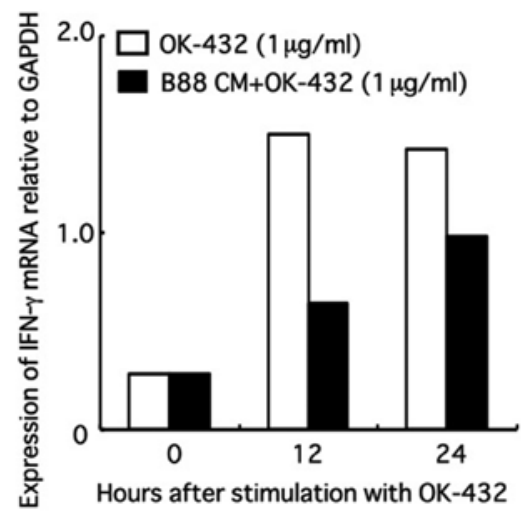

Figure 2. Effect of $\mathrm{CM}$ on IFN- $\gamma$ mRNA expression in PBMCs following stimulation with OK-432. In the presence of CM, PBMCs were stimulated with OK-432 for $24 \mathrm{~h}$, and then the expression of IFN- $\gamma$ mRNA was analyzed by RT-PCR. Densitometric analysis for the RT-PCR band was performed using ImageJ 1.38 software (National Institutes of Health, Bethesda, MD, USA).

$15 \mathrm{ng} / \mathrm{ml}$ ) to neutralize each cytokine. After neutralized-CM was added to PBMCs, cells were stimulated with OK-432 for $24 \mathrm{~h}$ and then the amount of IFN- $\gamma$ and IL-12 in culture supernatant was measured with an ELISA kit (BioSource International, Inc.). All neutralizing antibodies used were purchased from R\&D Systems (Minneapolis, MN, USA).

Statistical analysis. The data obtained are expressed as the means \pm standard deviation, using analysis of variance (ANOVA). $\mathrm{P}<0.05$ was considered to indicate a statistically significant difference.

\section{Results}

Association between cancer stage and serum concentration of IFN- $\gamma$ in patients with oral cancer following administration of $O K-432$. Twenty-four hours after the administration of OK-432, serum concentrations of IFN- $\gamma$ in patients with advanced cancer were significantly lower than those in patients with early cancer (Fig. 1).

Effect of CM on the expression of IFN- $\gamma$ mRNA in PBMCs following treatment with $O K-432$. IFN- $\gamma$ mRNA expression of PBMCs increased following stimulation with OK-432, but was significantly inhibited after replacement of CM-containing media at a CM (derived from B88 cells) volume of 1/2 (Fig. 2).

Effect of CM on IFN- $\gamma$ production from PBMCs following treatment with $O K-432$. IFN- $\gamma$ produced by PBMCs increased after stimulation with OK-432, but decreased in the presence of $\mathrm{CM}$ in a $\mathrm{CM}$ concentration-dependent manner. Inhibition of IFN- $\gamma$ production from PBMCs in the presence of CM was detected in all oral cancer cells used (Fig. 3).

Effect of CM on the cytotoxic activity of PBMCs following treatment with $O K-432$. Cytotoxic activities of PBMCs against K-562 cells (Fig. 4A) and Daudi cells (Fig. 4B) were enhanced in both cells following treatment with OK-432; however, activities were significantly inhibited after replacement of
A

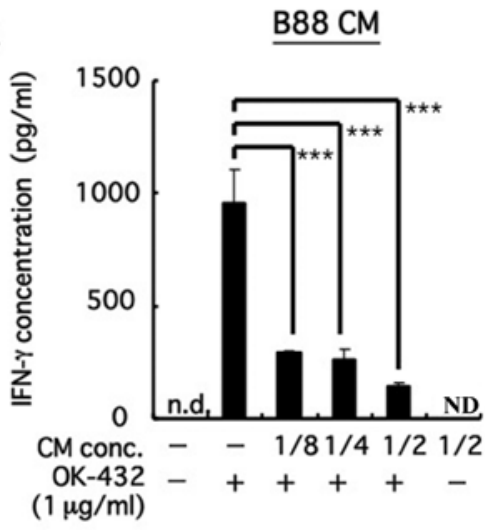

B

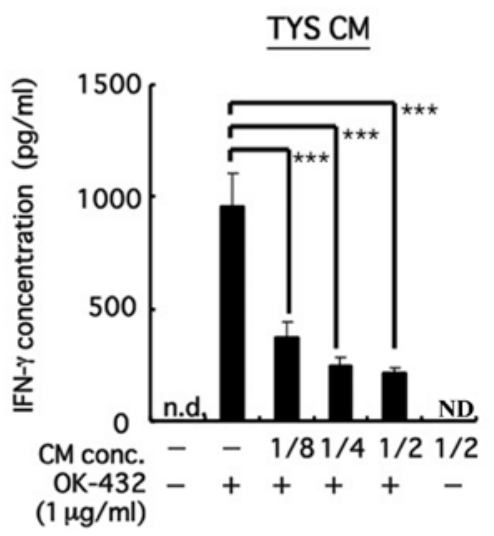

C

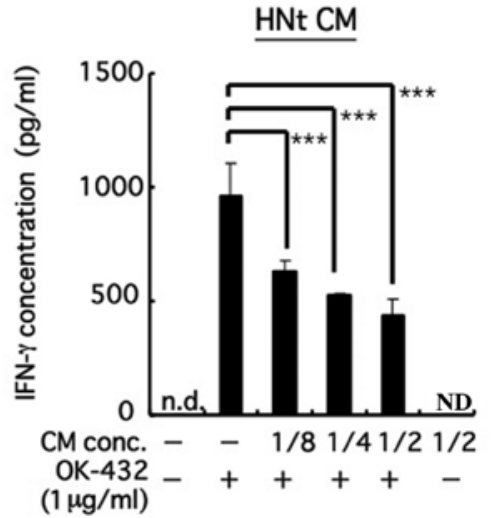

Figure 3. Effect of CM on IFN- $\gamma$ production from PBMCs following stimulation with $\mathrm{OK}-432$. In the presence of $\mathrm{CM}$, PBMCs were stimulated with OK-432 for $24 \mathrm{~h}$, and then the concentration of IFN- $\gamma$ was examined by ELISA. (A) B88 cells, (B) TYS cells, (C) HNt cells. ${ }^{* * * *} \mathrm{P}<0.001$. ND, not detectable.

CM-containing media at a CM (derived from B88 cells) volume of 1/2 (Fig. 4).

Effect of immunosuppressive cytokines on IFN- $\gamma$ production from PBMCs following treatment with $\mathrm{OK}-432$. Table I shows the concentration of each cytokine in CM derived from B88, TYS, and HNt cells. Of these cytokines, neutralization tests against representative immunosuppressive cytokines, IL-4, IL-6, IL-10, TGF- $\beta$ and VEGF, were conducted to elucidate the inhibitory mechanism of IFN- $\gamma$ production from PBMCs in the presence of CM. Despite the addition of CM derived from B88 cells and TYS cells pretreated with neutralizing Abs against these immunosuppressive cytokines, inhibition of IFN- $\gamma$ production from PBMCs was not restored (Fig. 5). By the addition of neutralizing Abs against IL- 6 and VEGF to 

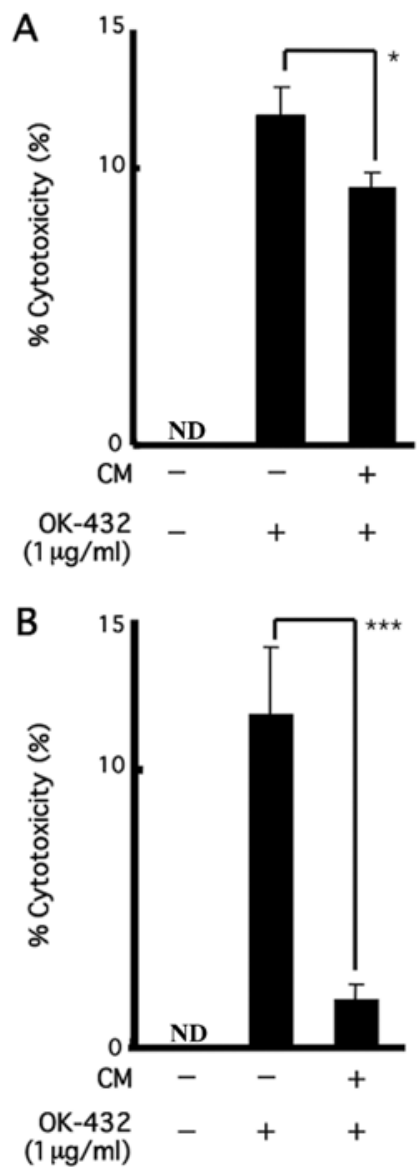

Figure 4. Effect of $\mathrm{CM}$ on the cytotoxic activity of PBMCs following stimulation with OK-432. In the presence of CM, PBMCs were stimulated with OK-432 for $24 \mathrm{~h}$, and then the cytotoxic activities of PBMCs against K-562 (A) and Daudi (B) cells were examined by the LDH assay. ${ }^{*} \mathrm{P}<0.05$; ${ }^{* * * *} \mathrm{P}<0.001$. ND, not detectable.

CM derived from TYS cells, inhibition of IFN- $\gamma$ production from PBMCs appears to have been restored (Fig. 5B and E). However, induction of IFN- $\gamma$ production from PBMCs was also observed only with the addition of neutralizing antibody in the absence of CM. These results indicate that IL-6 and VEGF are likely not the main cytokines affecting the inhibition of IFN- $\gamma$ production from PBMCs with CM.

\section{Discussion}

In the present study, we established an in vitro simulation model for immune status in cancer-burden patients by the addition of CM derived from oral cancer cells to PBMCs isolated from a healthy volunteer. Whether or not soluble factors derived from oral cancer cells affected IFN- $\gamma$ production from PBMCs following stimulation with OK-432 was then investigated. We found that, in the presence of $\mathrm{CM}$, enhanced production of IFN- $\gamma$ and cytotoxic activities of PBMCs following stimulation with OK-432 decreased in a CM concentration-dependent manner. Although IL-4, IL-6, IL-10, TGF- $\beta$ and VEGF were representative immunosuppressive cytokines that play critical roles in the inhibition of IFN- $\gamma$ production, they did not contribute to the inhibition of IFN- $\gamma$ production by $\mathrm{CM}$.
Table I. Concentration of cytokines in CM from oral cancer cell lines $(\mathrm{pg} / \mathrm{ml})$.

\begin{tabular}{lccccccc} 
Cells & IFN- $\gamma$ & IL-12 & IL-4 & IL-6 & IL-10 & TGF- $\beta$ & VEGF \\
\hline B88 & ND & 28.4 & 34.5 & 910 & ND & 107 & 4662 \\
TYS & ND & 23.8 & 23.4 & 1437 & ND & 113 & 5019 \\
HNt & ND & 24.4 & - & 1385 & ND & 70 & 3891
\end{tabular}

CM, conditioned medium; IFN- $\gamma$, interferon- $\gamma$; IL, interleukin; TGF- $\beta$, transforming growth factor- $\beta$; VEGF, vascular endothelial growth factor; ND, not detectable; -, not done.

In general, diverse immunosuppressive cytokines produced by cancer cells are known to contribute to the immune suppression of patients with cancer. For example, IL-6 is generally released by macrophages, but is also produced by cancer cells, which inhibits production of IFN- $\gamma$ from PBMCs (36). In the present study, high levels of IL-6 production were detected in all oral cancer cells used. It was also reported that the immunosuppressive status of patients with cancer caused by cachexia is induced by inhibition of IFN- $\gamma$ and acceleration of IL-6 production. TGF- $\beta$ is also known as an immunosuppressive cytokine produced by several types of cancer cells. It was demonstrated that by the neutralization of TGF- $\beta$ in $\mathrm{CM}$ and the addition of recombinant TGF- $\beta$, the immunosuppressive effect of TGF- $\beta$ was based on the inhibition of $\mathrm{CD}^{+}$ T-cell function (37). It was also clarified that TGF- $\beta$ in CM suppressed IFN $-\gamma$ production from PBMCs using pancreatic and liver cancer cells $(38,39)$. It is well known that VEGF is also secreted from cancer cells and stimulates growth and metastasis of cancer via angiogenesis. The immunosuppressive effects of VEGF are considered to occur by blocking the differentiation of bone marrow stem cells into dendritic cells and the maturation of dendritic cells and by inhibiting the antigen-presenting ability and cytokine production of dendritic cells $(40,41)$. The oral cancer cells used in the present study also secreted these representative immunosuppressive cytokines; however, these cytokines were not involved in the inhibition of IFN- $\gamma$ production from PBMCs by CM.

Immunosuppressive cytokines produced by PBMCs stimulated by cancer cell-derived soluble factors are also known to induce immunosuppression of patients with cancer. It has been reported that $\mathrm{CM}$ from kidney cancer cells or malignant melanoma cells enhanced the production of immunosuppressive cytokines such as IL-4, IL- 6 and IL-10 by PBMCs $(42,43)$. IL-10 is also known to be produced by PBMCs that are stimulated by OK-432 (44), followed by the inhibition of IFN- $\gamma$ production (45). In the present study, IL-10 levels were not detectable in CM derived from oral cancer cells, but were markedly induced by stimulation of OK-432, and were further induced with the addition of CM (data not shown). However, even if IL-10 is blocked by the neutralizing Ab, inhibition of IFN- $\gamma$ production from PBMCs by the addition of CM could not recover. Among the other immunosuppressive cytokines investigated in the present study, production of IL-4, TGF- $\beta$, or VEGF was not detected in PBMCs even after stimulation with OK-432 (data not shown). While production of IL-6 was 

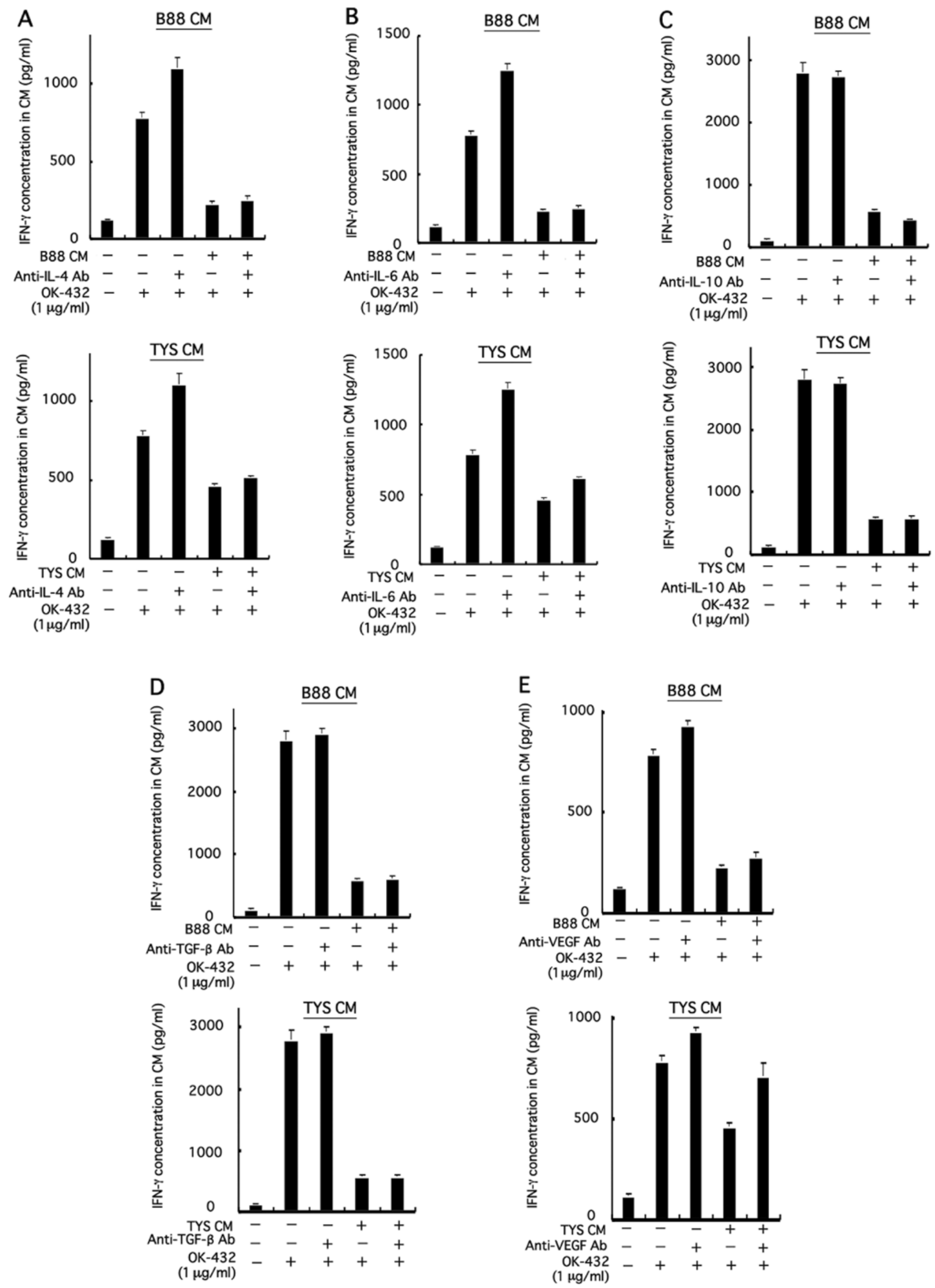

Figure 5. Effect of cytokines on IFN- $\gamma$ production from PBMCs following stimulation with OK-432. In the presence of CM pretreated with neutralizing Ab against (A) IL-4, (B) IL-6, (C) IL-10, (D) TGF- $\beta$ or (E) VEGF, PBMCs were stimulated with OK-432 for 24 h, and then the concentration of IFN- $\gamma$ in the supernatant was examined by ELISA. ${ }^{*} \mathrm{P}<0.05 ;{ }^{* * * *} \mathrm{P}<0.001$. NS, not significant. 
induced in PBMCs following stimulation with OK-432 (data not shown), IFN- $\gamma$ production from PBMCs inhibited by the addition of CM following stimulation with OK-432 did not recover even by the neutralization of IL-6. We thus concluded that representative immunosuppressive cytokines produced by cancer cells or PBMCs are not involved in the suppression of IFN- $\gamma$ production from PBMCs by the addition of CM. These results suggest that unknown molecules, excluding these representative immunosuppressive cytokines, may be involved in the inhibition of IFN- $\gamma$ production. Clarifying these unknown molecules may be a way to develop effective immunotherapy against oral cancer.

\section{References}

1. Okamoto H, Shoin S, Koshimura S and Shimizu R: Studies on the anticancer and streptolysin S-forming abilities of hemolytic streptococci. Jpn J Microbiol 11: 323-326, 1967.

2. Watanabe Y and Iwa T: Clinical value of immunotherapy with the streptococcal preparation OK-432 in non-small cell lung cancer. J Biol Response Mod 6: 169-180, 1987.

3. Katano $M$ and Torisu M: New approach to management of malignant ascites with a streptococcal preparation, OK-432. II. Intraperitoneal inflammatory cell-mediated tumor cell destruction. Surgery 93: 365-373, 1983.

4. Uchida $A$ and Micksche M: Intrapleural administration of OK-432 in cancer patients: activation of NK cells and reduction of suppressor cells. Int J Cancer 31: 1-5, 1983.

5. Uchida A, Micksche M and Hoshino T: Intrapleural administration of OK-432 in cancer patients: augmentation of autologous tumor killing activity of tumor-associated large granular lymphocytes. Cancer Immunol Immunother 18: 5-12, 1984.

6. Sato M, Yoshida H, Yanagawa T, Yura Y, Urata M, Atsumi M, Hayashi Y and Takegawa Y: Effects of intradermal administration of streptococcal preparation OK-432 on interferon and natural killer cell activities in patients with oral cancer. Int J Oral Surg 13: 7-15, 1984.

7. Sato M, Harada K, Yoshida H, Yura Y, Azuma M, Iga H, Bando T, Kawamata $\mathrm{H}$ and Takegawa Y: Therapy for oral squamous cell carcinoma by tegafur and streptococcal agent OK-432 in combination with radiotherapy: association of the therapeutic effect with differentiation and apoptosis in the cancer cells. Apoptosis 2: 227-238, 1997.

8. Oshimi K, Kano S, Takaku F and Okumura K: Augmentation of mouse natural killer cell activity by a streptococcal preparation, OK-432. J Natl Cancer Inst 65: 1265-1269, 1980.

9. Oshimi K, Wakasugi H, Seki H and Kano S: Streptococcal preparation OK-432 augments cytotoxic activity against an erythroleukemic cell line in humans. Cancer Immunol Immunother 9: 187-192, 1980

10. Matsubara S, Suzuki F and Ishida N: Induction of immune interferon in mice treated with a bacterial immunopotentiator OK-432. Cancer Immunol Immunother 6: 41-45, 1979.

11. Sato M, Hayashi Y, Yashida H, Yanagawa T, Yura Y, Urata M and Furumoto N: Effect of immunotherapy with a streptococcal preparation, OK-432, on the peripheral killer lymphocyte population in patients with head and neck cancer. Immunopharmacological Aspects of OK-432 in Humans. 1st edition. Excerpta Medica, Tokyo, pp78-88, 1986.

12. Kaji R, Yoshida H, Yanagawa $\mathrm{T}$ and Sato M: Monoclonal antibody to a human salivary adenocarcinoma cell line: augmentation of antibody-dependent cell-mediated cytotoxity activity by streptococcal preparation OK-432 in human salivary adenocarcinoma-bearing nude mice given the antibody. J Biol Response Mod 8: 488-500, 1989.

13. Nakahara S, Tsunoda T, Baba T, Asabe S and Tahara H: Dendritic cells stimulated with a bacterial products, OK-432, efficiently induce cytotoxic $\mathrm{T}$ lymphocytes specific to tumor rejection peptide. Cancer Res 63: 4112-4118, 2003.

14. Okamoto M, Kaji R, Kasetani H, Yoshida H, Moriya Y, Saito M and Sato M: Purification and characterization of interferon- $\gamma$ inducing molecule of OK-432, a penicillin-killed streptococcal preparation, by monoclonal antibody neutralizing interferon- $\gamma$ inducing activity of OK-432. J Immunother Emphasis Tumor Immunol 13: 232-242, 1993.
15. Okamoto M, Ohe G, Oshikawa T, Furuichi S, Nishikawa N, Tano T, Ahmed SU, Yoshida H, Moriya Y, Saito S and Sato M: Induction of Th1-type cytokines by lipoteichoic acid-related preparation isolated from OK-432, a penicillin-killed streptococcal agent. Immunopharmacology 49: 363-376, 2000.

16. Okamoto $M$ and Sato $M$ : Toll-like receptor signaling in anticancer immunity. J Med Invest 50: 9-24, 2003.

17. Okamoto $\mathrm{M}$ and Sato M: Effective molecule of a streptococcal preparation OK-432 and its molecular targets: significance for cancer immunotherapy. Rec Res Dev Infect Immun 1: 29-44, 2003.

18. Takada H, Kawabata Y, Arakaki R, Kusumoto S, Fukase K, Suda Y, Yoshimura T, Kokeguchi S, Kato K and Komuro T: Molecular and structural requirements of a lipoteichoic acid from Enterococcus hirae ATCC 9790 for cytokine-inducing, antitumor, and antigenic activities. Infect Immun 63: 57-65, 1995.

19. Okamoto M, Oshikawa T, Furuichi S, Nishikawa N, Tano T, Ahmed SU, Yoshida H, Matsubara S, Matsuno T and Sato M: Comparison of cytokine-inducing activity in a lipoteichoic acid-related molecule isolated from a penicillin-killed group A Streptococcus and from untreated bacteria. Int Immunopharmacol 1: 1957-1968, 2001.

20. Oshikawa T, Okamoto M, Ohe G, Furuichi S, Nishikawa H, Ahmed SU, Yoshida H, Moriya Y, Matsubara S, Ryoma Y, Saito $\mathrm{M}$ and Sato $\mathrm{M}$ : Isolation of a Th1-inducing molecule from OK-432, a streptococcal preparation, by a monoclonal antibody TS-2 that neutralizes the interferon- $\gamma$-inducing activity of OK-432: comparison of the enhancement of anti-tumor immunity between the TS-2-binding and TS-2-unbinding fraction. Int Immunopharmacol 3: 643-655, 2003.

21. Okamoto M, Ohe G, Furuichi S, Nishikawa N, Tano T, Ahmed SU, Yoshida H and Sato M: Enhancement of anti-cancer immunity by a lipoteichoic-acid-related molecule isolated from a penicillin-killed group A Streptococcus. Cancer Immunol Immunother 50: 408-416, 2001.

22. Okamoto M, Ohe G, Furuichi S, Nishikawa N, Tano T, Ahmed SU, Yoshida H and Sato M: Enhancement of anti-tumor immunity by lipoteichoic acid-related molecule isolated from OK-432, a streptococcal agent, in athymic nude mice bearing human salivary adenocarcinoma: Role of natural killer cells. Anticancer Res 226: 3229-3240, 2002

23. Shimazu R, Akashi S, Ogata H, Nagai Y, Fukudome K, Miyake K and Kimoto M: MD-2, a molecule that confers lipopolysaccharide responsiveness on Toll-like receptor 4. J Exp Med 189: 1777-1782, 1999.

24. Okamoto M, Oshikawa T, Ohe G, Furuichi S, Nishikawa N, Tano T, Ahmed SU, Yoshida H and Sato M: Severe impairment of anticancer effect of lipoteichoic acid-related molecule isolated from a penicillin-killed Streptococcus pyogenes in toll-like receptor 4-deficient mice. Int Immunopharmacol 1: 1789-1795, 2001.

25. Okamoto M, Oshikawa T, Tano T, Ohe G, Furuichi S, Nishikawa H, Ahmed SU, Akashi S, Miyake K, Takeuchi O, Akira S, Moriya Y, Matsubara S, Ryoma Y, Saito M and Sato M: Involvement of Toll-like receptor 4 signaling in interferon- $\gamma$ production and antitumor effect by a streptococcal agent OK-432. J Natl Cancer Inst 95: 316-326, 2003

26. UICC International Union Against Cancer. In: TNM Classification of Malignant Tumours. Sobin LH and Wittekind C, (eds). 5th edition. Wiley-Liss, New York, NY, pp17-50, 1997.

27. Uchida D, Begum NM, Almofti A, Nakashiro K, Kawamata H, Tateishi Y, Hamakawa H, Yoshida $\mathrm{H}$ and Sato M: Possible role of stromal cell-derived factor-1/CXCR4 signaling on lymph-node metastasis of oral squamous cell carcinoma. Exp Cell Res 290: 289-302, 2003.

28. Kawamata H, Nakashiro K, Uchida D, Harada K, Yoshida H and Sato M: Possible contribution of active MMP2 to lymph-node metastasis and secreted cathepsin L to bone invasion of newly established human oral-squamous-cancer cell lines. Int J Cancer 70: 120-127, 1997.

29. Yanagawa T, Hayashi Y, Yoshida H, Yura Y, Nagamine S, Bando T and Sato M: An adenoid squamous carcinoma-forming cell line established from an oral keratinizing squamous cell carcinoma expressing carcinoembryonic antigen. Am J Pathol 124: 496-509, 1986.

30. Anderson LC, Nilsson K and Gahmberg CG: K-562, a human erythroleukemic cell line. Int J Cancer 23: 143-147, 1979.

31. Klein E, Klein G, Nadkarmi JS, Nadkarmi JJ, Wigzell H and Clifford P: Surface IgM-kappa specificity on a Burkitt lymphoma cell in vivo and in derived culture lines. Cancer Res 28: $1300-1310,1968$. 
32. Boyüm A: Isolation of mononuclear cells and granulocytes from human blood. Isolation of mononuclear cells by one centrifugation, and of granulocytes by combining centrifugation and sedimentation at 1g. Scand J Clin Lab Invest Suppl 97: 77-89, 1968.

33. Nachlas MM, Margulies SI, Goldberg JD and Seligman AM: The determination of lactic dehydrogenase with a tetrazolium salt. Anal Biochem 1: 317-326, 1960.

34. Korzeniewski C and Callewaert DM: An enzyme-release assay for natural cytotoxicity. J Immunol Methods 64: 313-320, 1983

35. Decker T and Lohmann-Matthes ML: A quick and simple method for the quantitation of lactate dehydrogenase release in measurements of cellular cytotoxicity and tumor necrosis factor (TNF) activity. J Immunol Methods 115: 61-69, 1988.

36. Pasare $\mathrm{C}$ and Medzhitov R: Toll pathway-dependent blockade of $\mathrm{CD} 4{ }^{+} \mathrm{CD} 25^{+} \mathrm{T}$ cell-mediated suppression by dendritic cells. Science 299: 1033-1036, 2003.

37. Tada T, Ohzeki S, Utsumi K, Takiuchi H, Muramatsu M, Li XF, Shimizu J, Fujiwara $\mathrm{H}$ and Hamaoka T: Transforming growth factor- $\beta$-induced inhibition of $T$ cell functions and its relevance to immunosuppression in the tumor-bearing state. J Immunol 146: 1077-1082, 1991.

38. Bellone G, Turletti A, Artusio E, Mareschi K, Carbone A, Tibaudi D, Robecchi A, Emanuelli G and Rodeck U: Tumorassociated transforming growth factor- $\beta$ and interleukin-10 contribute to a systemic Th2 immune phenotype in pancreatic carcinoma patients. Am J Pathol 155: 537-547, 1999.

39. Mouri H, Sakaguchi K, Sawayama T, Senoh T, Ohta T, Nishimura M, Fujiwara A, Terao M, Shiratori Y and Tsuji T: Suppressive effects of transforming growth factor- $\beta 1$ produced by hepatocellular carcinoma cell lines on interferon- $\gamma$ production by peripheral blood mononuclear cells. Acta Med Okayama 56 309-315, 2002
40. Wang T, Niu G, Kortylewski M, Burdelya L, Shain K, Zhang S, Bhattacharya R, Gabrilovich D, Heller R, Coppola D, Dalton W, Jove R, Pardoll D and Yu H: Regulation of the innate and adaptive immune responses by Stat-3 signaling in tumor cells. Nat Med 10: 48-54, 2004

41. Gabrilovich D, Ishida T, Oyama T, Ran S, Kravtsov V, Nadaf S and Carbone DP: Vascular endothelial growth factor inhibits the development of dendritic cells and dramatically affects the differentiation of multiple hematopoietic lineages in vivo. Blood 92: 4150-4166, 1998

42. Smyth GP, Stapleton PP, Barden CB, Mestre JR, Freeman TA, Duff MD, Maddali S, Yan Z and Daly JM: Renal cell carcinoma induces prostaglandin E2 and T-helper type 2 cytokine production in peripheral blood mononuclear cells. Ann Surg Oncol 10: 455-462, 2003.

43. McCarter M, Clarke J, Richter D and Wilson C: Melanoma skews dendritic cells to facilitate a T helper 2 profile. Surgery 138: 321-328, 2005.

44. Fujimoto T, Duda RB, Szilvasi A, Chen X, Mai M and O'Donnell MA: Streptococcal preparation OK-432 is a potent inducer of IL-12 and a T helper cell 1 dominant state. J Immunol 158: 5619-5626, 1997.

45. Fiorentino DF, Zlotnic A, Vieira P, Mosmann TR, Howard M, Moore KW and Ogarra A: IL-10 acts on the antigen-presenting cell to inhibit cytokine production by Th1 cells. J Immunol 146: 3444-3451, 1991. 